\title{
Vigilance for HIV/AIDS: a cross-sectional study of 2 million adults in the United States
}

\author{
Irene Rethemiotaki
}

School of Production Engineering and Management, Technical University of Crete, Greece

\begin{abstract}
Introduction: This work aimed at studying human immunodeficiency virus (HIV) as well as the characteristics of individuals who have been tested for HIV in the United States during 2009-2018, with the ultimate goal to be found statistically significant predictors for HIV testing.

Material and methods: Statistical methods used to extract the results of this work were $\chi^{2}$ and oneway analysis of variance (ANOVA) test. A multiple logistic regression analysis was applied with odds ratio (OR) to find statistically significant prognostic factors for HIV testing.

Results: As specified by multiple logistic regression analyses, individuals aged 18-44 were eight times more likely to be tested for HIV (OR = 8.18), while Black or African Americans were three times more likely to be tested for the virus $(\mathrm{OR}=2.78)$. In addition, those who employ full-time $(\mathrm{OR}=2.17)$, and living with a partner $(\mathrm{OR}=1.80)$ were twice as likely to be tested for HIV. Finally, females $(\mathrm{OR}=1.24)$, who live in a large metropolitan statistical area $(\mathrm{OR}=1.61)$, with some college education status $(\mathrm{OR}=1.05)$, and living in a poor financial situation $(\mathrm{OR}=1.34)$ were more likely to be tested for the virus.

Conclusions: The results of this work highlight the prognostic characteristics of individuals, who are more likely to be tested for HIV, which reflects the vigilance for this incurable virus. Moreover, individuals with a higher degree of vigilance for HIV are more likely to be females in the age group of 18-44, financially independent, with a high level of education. On the contrary, individuals with a lower degree of vigilance for HIV, and therefore in high-risk groups, are more likely to be males, with less than a high school diploma education status, not poor, divorced or separated, with a private health insurance coverage, who do not employ and has never worked, living in the Midwest.
\end{abstract}

HIV AIDS Rev 2021; 20, 2: 96-101 DOI: https://doi.org/10.5114/hivar.2021.107235

Key words: human immunodeficiency virus, socio-economic factors, acquired immunodeficiency syndrome.

\section{Introduction}

Human immunodeficiency virus (HIV) is a virus that targets the cells of immune system, specifically the white blood cells (CD4), making an individual more susceptible to other infections and some types of cancer [1]. In the United States, approximately 36,400 newly HIV-infected people were in 2018 only, and 1.2 million people were living with

Address for correspondence: Irene Rethemiotaki, School of Production Engineering and Management, Technical University of Crete, Greece, e-mail: eirinireth@yahoo.gr

this virus [2]. Due to the lack of access to HIV services, 15,820 individuals died from HIV-related causes in 2018 in the United States [2]. Socio-economic problems, such as poverty and poor education, can increase the risk of HIV infection [3]. The gender and race with the highest HIV prevalence are females and Black Africans, respectively [4-8]. Poverty is an overarching factor that increases the disparity

Article history:

Received: 24.05.2020

Received in revised form: 29.09.2020

Accepted: 30.09 .2020

Available online: 30.06 .2021
International Journal of HIV-Related Problems

HIV \& AIDS

R e vi e w 
Table 1. Characteristics of individuals, who have been tested for HIV: United States 2009-2018

\begin{tabular}{|c|c|c|c|}
\hline Factor & $n$ & $\%$ & $p$-value \\
\hline \multicolumn{4}{|l|}{ Gender } \\
\hline Male & 488,198 & 45.0 & \multirow{2}{*}{$<0.05$} \\
\hline Female & 398,850 & 55.0 & \\
\hline \multicolumn{4}{|l|}{ Age } \\
\hline $18-44$ & 516,428 & 58.2 & \multirow{4}{*}{$<0.05$} \\
\hline $45-64$ & 300,658 & 33.9 & \\
\hline $65-74$ & 52,332 & 5.9 & \\
\hline$\geq 75$ & 17,627 & 2.0 & \\
\hline \multicolumn{4}{|l|}{ Race } \\
\hline White & 650,885 & 76.0 & \multirow{3}{*}{$<0.05$} \\
\hline Black or African American & 162,476 & 19.0 & \\
\hline Asian & 42,859 & 5.0 & \\
\hline \multicolumn{4}{|l|}{ Origin } \\
\hline Hispanic or Latino & 151,650 & 9.2 & \multirow{5}{*}{$<0.05$} \\
\hline $\begin{array}{l}\text { Mexican or Mexican } \\
\text { American }\end{array}$ & 85,687 & 5.2 & \\
\hline Not Hispanic or Latino & 735,395 & 44.7 & \\
\hline White, single-race & 517,293 & 31.4 & \\
\hline $\begin{array}{l}\text { Black or African American, } \\
\text { single-race }\end{array}$ & 155,055 & 9.4 & \\
\hline \multicolumn{4}{|l|}{ Education } \\
\hline $\begin{array}{l}\text { Less than a high school } \\
\text { diploma }\end{array}$ & 86,525 & 10.9 & \multirow{4}{*}{$<0.05$} \\
\hline High school diploma & 173,385 & 21.8 & \\
\hline Some college & 253,869 & 32.0 & \\
\hline Bachelor's degree or higher & 280,708 & 35.3 & \\
\hline \multicolumn{4}{|l|}{ Employment } \\
\hline Employed & 428,987 & 40.7 & \multirow{5}{*}{$<0.05$} \\
\hline Full-time & 355,948 & 33.8 & \\
\hline Part-time & 67,574 & 6.4 & \\
\hline $\begin{array}{l}\text { Not employed but has } \\
\text { worked previously }\end{array}$ & 178,651 & 16.9 & \\
\hline $\begin{array}{l}\text { Not employed and has } \\
\text { never worked }\end{array}$ & 23,476 & 2.2 & \\
\hline \multicolumn{4}{|l|}{ Family income } \\
\hline Less than $\$ 35.000$ & 262,409 & 18.8 & \multirow{6}{*}{$<0.05$} \\
\hline$\leq \$ 35.000$ & 565,002 & 40.6 & \\
\hline$\$ 35.000-\$ 49.999$ & 103,550 & 7.4 & \\
\hline$\$ 50.000-\$ 74.999$ & 141,940 & 10.2 & \\
\hline$\$ 75.000-\$ 99.999$ & 100,912 & 7.2 & \\
\hline$\geq \$ 100.000$ & 218,601 & 15.7 & \\
\hline \multicolumn{4}{|l|}{ Poverty status } \\
\hline Poor & 123,327 & 14.7 & \multirow{3}{*}{$<0.05$} \\
\hline Nearly poor & 150,109 & 17.8 & \\
\hline Not poor & 568,299 & 67.5 & \\
\hline
\end{tabular}

Table 1. Cont.

\begin{tabular}{|c|c|c|c|}
\hline Factor & $n$ & $\%$ & $p$-value \\
\hline \multicolumn{4}{|l|}{ Health insurance coverage } \\
\hline \multicolumn{4}{|l|}{ Under 65} \\
\hline Private & 515,559 & 63.4 & \multirow{4}{*}{$<0.05$} \\
\hline Medicaid & 114,558 & 14.1 & \\
\hline Other coverage & 45,762 & 5.6 & \\
\hline Uninsured & 137,627 & 16.9 & \\
\hline \multicolumn{4}{|l|}{65 and over } \\
\hline Private & 28,791 & 47.9 & \multirow{4}{*}{$<0.05$} \\
\hline Medicare and Medicaid & 6,426 & 10.7 & \\
\hline Medicare only & 15,921 & 26.5 & \\
\hline Other coverage & 8,976 & 14.9 & \\
\hline \multicolumn{4}{|l|}{ Marital status } \\
\hline Married & 90,237 & 50.8 & \multirow{5}{*}{$<0.05$} \\
\hline Widowed & 23,871 & 2.7 & \\
\hline Divorced or separated & 123,262 & 13.9 & \\
\hline Never married & 198,383 & 22.4 & \\
\hline Living with a partner & 449,982 & 10.2 & \\
\hline \multicolumn{4}{|c|}{ Place of residence (MSA: Metropolitan statistical area) } \\
\hline $\begin{array}{l}\text { Large MSA (population size } \\
1 \text { million or more) }\end{array}$ & 524,631 & 59.1 & \multirow{3}{*}{$<0.05$} \\
\hline $\begin{array}{l}\text { Small MSA (less than } \\
1 \text { million) }\end{array}$ & 256,917 & 29.0 & \\
\hline Not in MSA & 105,496 & 11.9 & \\
\hline \multicolumn{4}{|l|}{ Region } \\
\hline Northeast & 155,879 & 17.6 & \multirow{4}{*}{$<0.05$} \\
\hline Midwest & 172,991 & 19.5 & \\
\hline South & 338,820 & 38.2 & \\
\hline West & 219,357 & 24.7 & \\
\hline
\end{tabular}

associated with HIV prevalence due to low coverage of HIV testing and counseling [9-12].

It is of utmost importance to acknowledge the seriousness of HIV infection, which in turn reflects the responsibility of underlying factors that lead to barriers in health services. For this purpose, this work studied HIV in the United States during the period 2009-2018 to evaluate prognostic factors for HIV testing.

\section{Material and methods}

The data used in this work originate from the National Health Interview Survey dataset [13] and cover the period 2009-2018. To be identified, the adults, who have been tested for HIV, each household was asked to answer the question: "Except for tests you may have had as part of blood donations, have you ever been tested for HIV?". All adults 
Table 2. Socio-economic characteristics: United States 2009-2018. Statistically significant predictors of HIV testing in the US using multivariate logistic regression

\begin{tabular}{|c|c|c|c|c|}
\hline Factor & Cases & Controls & Odds ratio $(95 \% \mathrm{Cl})$ & $p$-value \\
\hline \multicolumn{5}{|l|}{ Gender } \\
\hline Female & 488,198 & 691,062 & $1.24(1.23-1.25)$ & \multirow{2}{*}{$<0.05$} \\
\hline Male & 398,850 & 700,482 & 1.00 & \\
\hline \multicolumn{5}{|l|}{ Age } \\
\hline $18-44$ & 516,428 & 562,309 & $8.18(8.05-8.31)$ & \multirow{4}{*}{$<0.05$} \\
\hline $45-64$ & 300,658 & 482,278 & $5.55(5.46-5.64)$ & \\
\hline $65-74$ & 52,332 & 189,836 & $2.45(2.41-2.50)$ & \\
\hline$\geq 75$ & 17,627 & 157,122 & 1.00 & \\
\hline \multicolumn{5}{|l|}{ Race } \\
\hline White & 650,885 & $1,159,979$ & $1.09(1.08-1.10)$ & \multirow{3}{*}{$<0.05$} \\
\hline Black or African American & 162,476 & 113,930 & $2.78(2.74-2.81)$ & \\
\hline Asian & 42,859 & 83,554 & 1.00 & \\
\hline \multicolumn{5}{|l|}{ Origin } \\
\hline Hispanic or Latino & 151,650 & 194,862 & $0.54(0.54-0.55)$ & \multirow{5}{*}{$<0.05$} \\
\hline Mexican or Mexican American & 85,687 & 126,741 & $0.47(0.47-0.48)$ & \\
\hline Not Hispanic or Latino & 735,395 & $1,196,682$ & $0.43(0.42-0.43)$ & \\
\hline White, single-race & 517,293 & 981,235 & $0.37(0.36-0.37)$ & \\
\hline Black or African American, single-race & 155,055 & 108,940 & 1.00 & \\
\hline \multicolumn{5}{|l|}{ Education } \\
\hline Less than a high school diploma & 86,525 & 170,663 & $0.67(0.66-0.67)$ & \multirow{4}{*}{$<0.05$} \\
\hline High school diploma & 173,385 & 325,581 & $0.70(0.70-0.71)$ & \\
\hline Some college & 253,869 & 319,602 & $1.05(1.04-1.06)$ & \\
\hline Bachelor's degree or higher & 280,708 & 372,157 & 1.00 & \\
\hline \multicolumn{5}{|l|}{ Employment } \\
\hline Employed & 428,987 & 568,731 & $2.08(2.05-2.11)$ & \multirow{5}{*}{$<0.05$} \\
\hline Full-time & 355,948 & 452,947 & $2.17(2.13-2.20)$ & \\
\hline Part-time & 67,574 & 107,201 & $1.74(1.71-1.77)$ & \\
\hline Not employed but has worked previously & 178,651 & 348,864 & $1.41(1.39-1.43)$ & \\
\hline Not employed and has never worked & 2,476 & 64,815 & 1.00 & \\
\hline \multicolumn{5}{|l|}{ Family income } \\
\hline Less than $\$ 35.000$ & 262,409 & 395,827 & $1.01(1.01-1.02)$ & \multirow{6}{*}{$<0.05$} \\
\hline$\$ 35.000$ or more & 565,002 & 873,339 & $0.92(0.91-0.92)$ & \\
\hline$\$ 35.000-\$ 49.999$ & 103,550 & 168,874 & $0.87(0.86-0.88)$ & \\
\hline$\$ 50.000-\$ 74.999$ & 141,940 & 229,284 & $0.88(0.87-0.89)$ & \\
\hline$\$ 75.000-\$ 99.999$ & 100,912 & 163,471 & $0.88(0.87-0.89)$ & \\
\hline$\$ 100.000$ or more & 218,601 & 311,706 & 1.00 & \\
\hline \multicolumn{5}{|l|}{ Poverty status } \\
\hline Poor & 123,327 & 148,358 & $1.34(1.33-1.35)$ & \multirow{3}{*}{$<0.05$} \\
\hline Nearly poor & 150,109 & 224,392 & $1.08(1.07-1.09)$ & \\
\hline Not poor & 568,299 & 918,820 & 1.00 & \\
\hline
\end{tabular}


Table 2. Cont.

\begin{tabular}{|c|c|c|c|c|}
\hline Factor & & Control cases & Odds ratio $(95 \% \mathrm{Cl})$ & $\mathrm{p}$-value \\
\hline \multicolumn{5}{|l|}{ Health insurance coverage } \\
\hline \multicolumn{5}{|l|}{ Under 65} \\
\hline Private & 515,559 & 726,945 & $0.91(0.90-0.92)$ & \multirow{4}{*}{$<0.05$} \\
\hline Medicaid & 114,558 & 95,557 & $1.54(1.52-1.56)$ & \\
\hline Other coverage & 45,762 & 38,840 & $1.51(1.49-1.54)$ & \\
\hline Uninsured & 137,627 & 177,365 & 1.00 & \\
\hline \multicolumn{5}{|l|}{65 and over } \\
\hline Private & 28,791 & 170,285 & $0.42(0.41-0.43)$ & \multirow{4}{*}{$<0.05$} \\
\hline Medicare and Medicaid & 6,426 & 21,275 & $0.76(0.73-0.79)$ & \\
\hline Medicare only & 15,921 & 91,514 & $0.43(0.42-0.45)$ & \\
\hline Other coverage & 8,976 & 22,643 & 1.00 & \\
\hline \multicolumn{5}{|l|}{ Marital status } \\
\hline Living with a partner & 90,237 & 77,635 & $1.80(1.78-1.82)$ & \multirow{5}{*}{$<0.05$} \\
\hline Widowed & 23,871 & 109,128 & $0.91(0.91-0.92)$ & \\
\hline Divorced or separated & 123,262 & 132,521 & $0.34(0.33-0.34)$ & \\
\hline Never married & 198.383 & 307,994 & $1.44(1.43-1.45)$ & \\
\hline Married & 449,982 & 762,523 & 1.00 & \\
\hline \multicolumn{5}{|l|}{ Place of residence (MSA: Metropolitan statistical area) } \\
\hline Large MSA (population size 1 million or more) & 524,631 & 716,581 & $1.61(1.60-1.62)$ & \multirow{3}{*}{$<0.05$} \\
\hline Small MSA (less than 1 million) & 256,917 & 442,183 & $1.28(1.27-1.29)$ & \\
\hline Not in MSA & 105,496 & 232,781 & 1.00 & \\
\hline \multicolumn{5}{|l|}{ Region } \\
\hline Northeast & 155,879 & 246,940 & $0.89(0.88-0.90)$ & \multirow{4}{*}{$<0.05$} \\
\hline Midwest & 172,991 & 343,931 & $0.71(0.70-0.71)$ & \\
\hline South & 338,820 & 490,001 & $0.97(0.97-0.98)$ & \\
\hline West & 219,357 & 310,671 & 1.00 & \\
\hline
\end{tabular}

examined were $2,278,592$, while the number of individuals who have been tested for HIV was 887,048 . The statistical methods used to extract the results of this work included $\chi^{2}$ test for categorical and one-way analysis of variance (ANOVA) for continues variables, in order to verify the null hypothesis that the mean of adults in the United States, who have been tested for HIV did not differ according to their socio-economic characteristics, such as gender, age, race, origin, parent's education, family income, poverty status, health insurance coverage, current health status, family structure, place of residence, and region. A multiple logistic regression analysis was used with odds ratio (OR) to obtain statistically significant prognostic factors for HIV testing. A cross-sectional study was carried out, where individuals were classified into two groups: the case group and the control group. More specifically, the control group was all target population that has never been tested for HIV. In contrast, the case group was all adults with the same socio-economic characteristics as the control group, who has been tested for this virus. The data were weighted before analyzed. Predictors were represented using OR and 95\% confidence interval, and $p<0.05$ was considered as statistically significant. More precisely, OR has been used in order to be compared the relative odds of the occurrence of outcome of interest (characteristics of participants), given exposure to the variable of interest (HIV testing). An OR $>1$ means that the characteristic was associated with higher odds of outcome, and finally, an $\mathrm{OR}<1$ implies that the characteristic was associated with lower odds of the outcome [14]. The study was carried out using IBM SPSS 25 software package for Windows.

\section{Results}

To test the null hypothesis that the mean of US individuals, who have been tested for HIV, did not differ in accordance with their socio-economic characteristics, using $\chi^{2}$ test and one-way analysis of variance (ANOVA). As shown in Table 1, most individuals who have been tested for HIV were females (55\%), in the age group of 18-44 (58.2\%), while the most common origin and race were not Hispanic or Lati- 


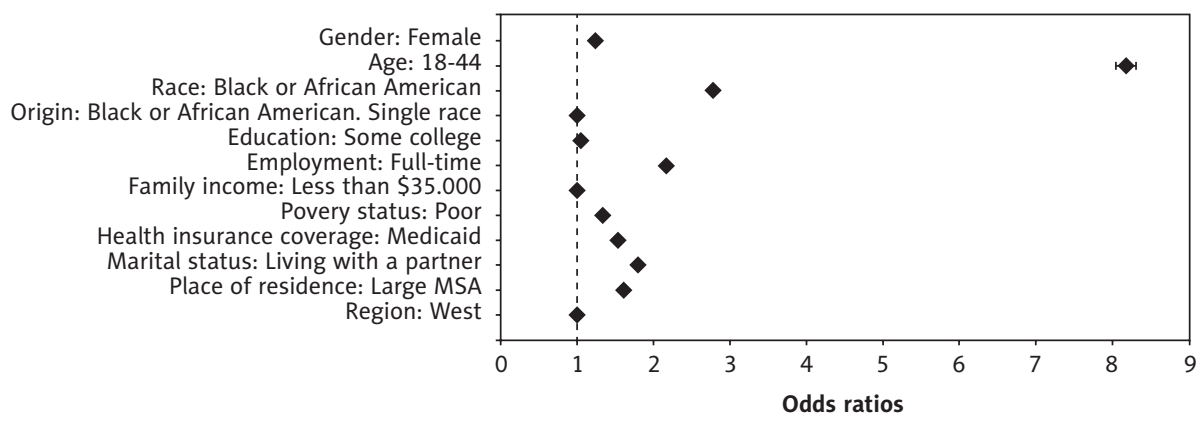

Figure 1. Prognostic factors for HIV testing with odds ratios

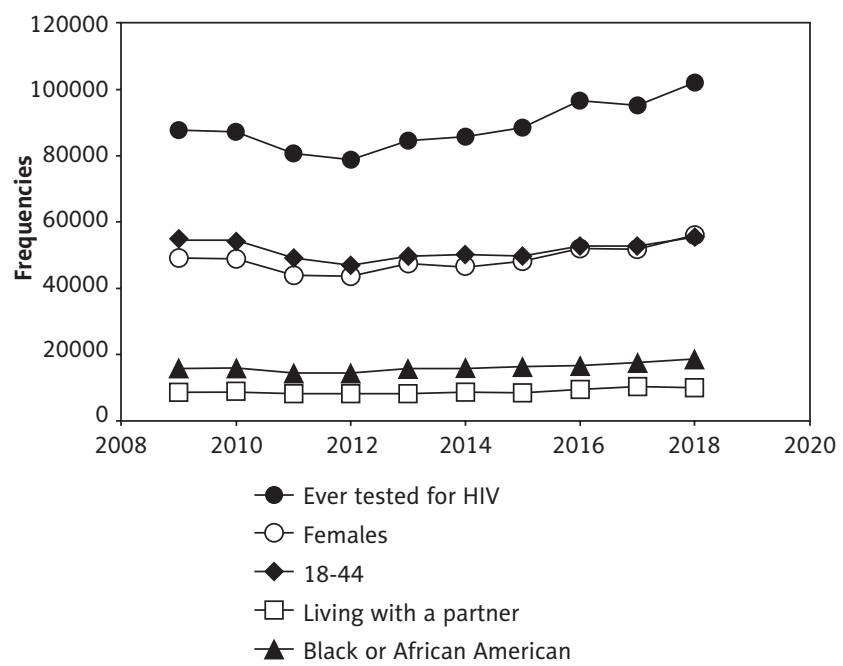

Figure 2. The trend in HIV as well as the trend in characteristics of individuals, who have been tested for HIV, with the highest odds ratios during the years 2009-2018 in the United States

no $(44.7 \%)$ and white $(76 \%)$, respectively. Moreover, most of them had a bachelor's degree or higher (35.3\%), were employed (40.7\%), were not poor $(67.5 \%)$, having a family income of $\$ 35.000$ or more (40.6\%), and a private health insurance coverage $(63.4 \%)$. Finally, the region with the most frequent occurrence of HIV testing was the South (38.2\%), with a population size of one million or more (59.1\%).

Table 2 represents the multiple logistic regression analysis using odds ratios, with the ultimate goal to be found statistically significant predictors for HIV testing. As can be seen in Table 2, all prognostic factors were statistically significant $(p<0.05)$. Based on multiple logistic regression, females $(\mathrm{OR}=1.24)$, in the age group of $18-44(\mathrm{OR}=8.18)$ were eight times more likely to be tested for HIV. Black or African Americans were three times more likely to be tested for HIV (OR = 2.78), while those living with a partner $(\mathrm{OR}=1.80)$ and employed full-time $(\mathrm{OR}=2.17)$ were twice as likely to be tested for the disease. Finally, individuals who live in a large metropolitan statistical area $(\mathrm{OR}=1.61)$, with some college education status $(\mathrm{OR}=1.05)$, and living in a poor financial situation $(\mathrm{OR}=1.34)$, and Medicaid health insurance coverage ( $\mathrm{OR}=1.54)$ were more likely to be tested for HIV.

Figure 1 represents the trend in HIV testing as well as the trend in characteristics of individuals, who have been tested for HIV, with the highest OR during the years 2009-2018 in the United States. HIV testing has increased during the years 2009 to 2018. Figure 2 shows the prognostic factors for HIV testing with odds ratios, including age, which ranks first, followed by race, employment, and marital status.

\section{Discussion}

It is worth noting that the frequencies of HIV testing in the United States during the years 2009-2018 were rising, reflecting a higher degree of awareness for HIV. It was also noted that females, aged 18-44, Black or African-Americans, poor, employing full time, living with a partner, and having some college education were more likely to be tested for HIV. High level of education of females combined with their financial independence reflects the ability to choose low-risk sexual partners, thus reducing the risk of HIV infection. This is consistent with other studies showing that improving educational and economic status of women determine their bargaining power in partner's decision $[15,16]$.

On the contrary, males, divorced or separated, who were not employed and had never worked, with a low level of education had the lowest odds ratio for vigilance for HIV testing. Prior studies have linked low education levels, unemployment, appreciably reduced marital rates, and upcoming increase of one-person households, with greater HIV prevalence [17]. Moreover, individuals who have been socially or economically marginalized proved to be more vulnerable to HIV infection [18].

Effective HIV prevention strategies include substance abuse treatment as well as mental health treatment. More specifically, amphetamine and methamphetamine derivative have been found to be associated with high-risk sexual behaviors, such as having multiple sexual partners [19]. Furthermore, individuals who have been recently diagnosed with HIV were found to have fewer supportive families, and 
had more negative self-image as well as premorbid trauma experiences, such as childhood sexual abuse [20].

HIV test is the necessary first step in involving infected people in HIV-related healthcare. Testing later during HIV infection translates into medical care later, and therefore possible delays in treatment resulting in serious effects on the risk of HIV transmission.

This study's importance lies in the interaction of multiple socio-economic variables with HIV testing, which demonstrates the complexity and multi-dimensional nature of vigilance as well as the various roles of these dimensions during the course of life, which in turn reflects the risk of HIV infection.

One limitation of the present study is that data were collected through personal household interviews. Non-disclosure of such information by participants was possible due to memory and/ or social bias.

\section{Conclusions}

This paper emphasizes the prognostic characteristics of individuals, who are more likely to be tested for HIV, which indicates the vigilance for this incurable virus. Moreover, individuals with a higher degree of vigilance for HIV are more likely to be females, in the age group of 18-44, poor, Black or African Americans, financially independent, and with a high level of education. On the contrary, individuals with a lower degree of vigilance for HIV, and therefore high-risk groups, are more likely to be males, with less than a high school diploma education status, not poor, divorced or separated, with a private health insurance coverage, who do not employ and has never worked, and living in the Midwest.

\section{Conflict of interest}

The authors declare no conflict of interest with respect to the research, authorship, and/or publication of this article.

\section{References}

1. WHO. HIV/AIDS, 2019. Available from: https://www.who.int/ news-room/fact-sheets/detail/hiv-aids.

2. CDC. Diagnoses of HIV Infection in the United States and Dependent Areas, 2018. HIV Surveillance Report 2020; 31.

3. Tladi L. Poverty and HIV/AIDS in South Africa: an empirical contribution. SAHARA J 2006; 3: 369-381.

4. Shisana O, Rehle T, Simbayi LC, Zuma K, Jooste S, Zungu N, et al. South African national HIV prevalence, incidence and behavior survey, 2012. HSRC Press, Cape Town 2014.

5. Weine SM, Kashuba AB. Labor migration and HIV risk: a systematic review of the literature. AIDS Behav 2012; 16: 1605-1621.

6. Gilbert L, Selikow TA. The epidemic in this country has the face of a woma: gender and HIV/AIDS in South Africa. Afr J AIDS Res 2011; 10 (Suppl): 325-334.

7. Williams DR, Priest N, Anderson NB. Understanding associations among race, socioeconomic status, and health: patterns and prospects. Health Psychol 2016; 35: 407-411.

8. Shisana O, Zungu N, Evans M, Rehle T, Risher K, Celentano D. The case for expanding the definition of 'key populations' to inclu- de high-risk groups in the general population to improve targeted HIV prevention efforts. S Afr Med J 2015; 105: 664-669.

9. Pascoe SJS, Langhaug LF, Mavhu W, Hargreaves J, Jaffar S, Hayes R, et al. Poverty, food insufficiency and HIV infection and sexual behaviour among young rural Zimbabwean women. PLoS One 2015; 10: $\mathrm{e} 0115290$.

10. Awoleye OJ, Thron C. Determinants of human immunodeficiency virus (HIV) infection in Nigeria: a synthesis of the literature. J AIDS HIV Res 2015; 7: 117-129.

11. Sia D, Onadja Y, Nandi A, Foro A, Brewer T. What lies behind gender inequalities in HIV/AIDS in sub-Saharan African countries: evidence from Kenya, Lesotho and Tanzania. Health Policy Plan 2013; 29: 938-949.

12. Zembe YZ, Townsend L, Thorson A, Ekström AM. "Money talks, bullshit walks" interrogating notions of consumption and survival sex among young women engaging in transactional sex in postapartheid South Africa: a qualitative enquiry. Global Health 2013; 9: 28.

13. National Center for Health Statistics. Data file documentation, National Health Interview Survey, 2016. Available from: https://www. cdc.gov/nchs/nhis.htm.

14. Szumilas M. Explaining odds ratios [published correction appears in J Can Acad Child Adolesc Psychiatry. 2015 Winter;24(1):58]. J Can Acad Child Adolesc Psychiatry 2010; 19: 227-229.

15. Reniers G. Marital strategies for regulating exposure to HIV. Demography 2008; 45: 417-438.

16. Osuafor GN, Mturi J. Attitude towards sexual control among women in conjugal union in the era of the HIV/AIDS epidemic in Mahikeng, South Africa. Afr Popul Stud 2014; 28: 538.

17. Hunter M. The changing political economy of sex in South Africa: the significance of unemployment and inequalities to the scale of the AIDS pandemic. Soc Sci Med 2007; 64: 689-700.

18. Wabiri N, Taffa N. Socio-economic inequality and HIV in South Africa. BMC Public Health 2013; 13: 1037.

19. Mah TL, Halperin DT. Concurrent sexual partnerships and the HIV epidemics in Africa: evidence to move forward. AIDS Behav 2010; 14: 11-16.

20. Pellowski JA, Kalichman SC, Matthews KA, Adler N. A pandemic of the poor: social disadvantage and the U.S. HIV epidemic. Am Psychol 2013; 68: 197-209. 